\title{
1981 2010 年中国气候区划
}

郑景云 ${ }^{(1)}$ ，六娟娟 ${ }^{(1)}$ ，葛全胜 ${ }^{(1)^{*}}$, 郝志新 ${ }^{(1)}$ ，尹云鹤 ${ }^{(1)}$, 廖要明 ${ }^{(2)}$

(1) 中国科学院地理科学与资源研究所, 北京 100101;

(2) 国家气候中心, 北京 100081

* 联系人, E-mail: geqs@igsnrr.ac.cn

2012-12-27 收稿, 2013-04-26 接受, 2013-08-21 网络版发表

公益性行业(气象)科研专项(GYHY201106018)、全球变化研究国家重大科学研究计划(2010CB950103)和科技基础性工作专项 (2011FY120300)资助

\begin{abstract}
摘要 根据我国 658 个站 1981 2010 年日气象观测数据, 以日平均气温稳定 $\geqslant 10^{\circ} \mathrm{C}$ 的日数、年 干燥度、7月平均气温为划分温度带、干湿区、气候区的主要指标，以 1 月平均气温、年降水 量为温度带、干湿区划分的辅助指标, 并参考日平均气温稳定 $\geqslant 10^{\circ} \mathrm{C}$ 的积温及极端最低气温的 多年平均值等指标，对我国 1981 2010 年气候状况进行了区划，将我国分为 12 个温度带、24 个干湿区、56 个气候区。与 1951 1980 年相比, 受气候增暖影响, 1981 2010 年间我国东部多 个温度带界线出现了北移, 其中暖温带北界东段最大北移超过 1 个纬度, 北亚热带北界东段 平均北移 1 个纬度, 中亚热带北界中段最大北移 2 个纬度, 南亚热带北界西段北移 $0.5 \sim 2.0$ 个 纬度; 西部因受地形影响, 温度带水平移动不显著, 但在青藏高原有亚寒带范围缩小、温带范 围扩大趋势. 同时, 因华北、东北东南部、西北东部降水减少, 北方半千旱与半湿润分界线东 移与南进, 其中 $36^{\circ} \sim 41^{\circ} \mathrm{N}$ 间的移动幅度达 $0.5 \sim 2.5$ 经度; 但西北的河西走廊、新疆及青藏高 原的千旱区、半千旱区总体转湿.
\end{abstract}

\section{关键词}

中国

1981 2010 年

气候区划

区划界线变化
气候区划的目的是从综合角度揭示气候状况的 区域分异规律, 以便系统了解各地的气候特征, 对各 地、各行业有针对性地利用气候资源、趋利避害及人 类响应与适应未来气候变化等都具有重要意义. 全 球变化背景下气候区域分异格局如何变化是当前国 际学术界关注的一个重要科学问题, 已有许多学者 通过资料更新重新进行气候区划、探讨 20 世纪气候 变化(特别是全球增暖)导致的气候区划变动特征 ${ }^{[1 ~ 4]}$. 如 Kalvova 等人 ${ }^{[2]}$ 根据 1961 1990 年的全球气候资料, 采用柯本气候分类方法重新对世界气候进行 2 级区 划, 并比较其与 20 世纪初期世界气候区划的异同, 结果发现: 1961 1990 年较 20 世纪初期, 热带、温带 和寒带等气候带范围分别扩大了 $1.86 \%, 0.45 \%$ 和 $1.31 \%$, 干燥和极地气候带范围则分别缩小了 $1.89 \%$
和 $1.72 \%$. Kottek 等人 ${ }^{[3]}$ 和 Peel 等人 ${ }^{[4]}$ 最近又分别将 资料更新至 2000 年, 采用柯本-盖革气候分类方法重 新编制了世界气候 3 级区划图.

气候区划工作已在我国开展近百年，大致经历 3 个阶段: 一是 20 世纪 30 40 年代, 方法多借鉴当时欧 美的气候分类分区法, 如采用年或月平均气温、年降水 量等指标, 并结合自然状况划分气候的区域类型 ${ }^{[5 \sim 8]}$. 因当时我国气象测站点有限、观测时断时续，气象资料 不完整，故这些区划虽指出中国气候地带性的宏观特 征, 但区划界线具体位置划分存在较大主观性.

二是 20 世纪 50 80 年代中期, 我国已有了一定 的气象观测资料积累, 又恰逢当时国家需要气候区 划作为农业生产和经济建设布局的参考依据，因而 在借鉴欧美气候分类方法基础上, 发展形成了适合

引用格式: 郑景云, 市娟娟, 葛全胜, 等. 1981 2010 年中国气候区划. 科学通报, 2013, 58: 3088-3099 Zheng J Y, Bian J J, Ge Q S, et al. The climate regionalization in China for 1981-2010 (in Chinese). Chin Sci Bull (Chin Ver), 2013, 58: 3088-3099, doi: 10.1360/972012-1491 
我国自然环境与气候特征的区划原则、指标和方法; 提出了以日平均气温稳定 $\geqslant 10^{\circ} \mathrm{C}$ 积温及最冷候气温、 或最冷月气温、或极端最低气温与干燥度指标划分全 国热量资源与干湿状况的区划方案和方法, 形成了 以热量指标为一级、干湿指标为二级，同时在二级基 础上进行三级气候区划分的区划等级理论体系, 并 在利用谢梁尼诺夫的水热系数计算干燥度时, 根据 中国季风气候特点对其中的相关经验系数进行了修 订 ${ }^{[9]}$. 根据这一区划方法, 再结合中国地形特点和行 政区划状况，中国科学院自然区划工作委员第一次 较系统地编制了我国气候区划方案 ${ }^{[9]}$. 此后, 中央气 象局又在这一气候区划方案基础上, 采用 1951 1960 年全国各地气象观测资料, 重新根据彭曼公式计算了 可能蒸散量和干燥度 ${ }^{[10]}$, 对区划方案进行了充实和修 订, 同时采用各季干燥度或日平均气温稳定 $\geqslant 10^{\circ} \mathrm{C}$ 积 温(东北地区)、最热月平均气温(青藏高原地区)等指标 划分三级气候区界线, 弥补了早期气候区划在划分三 级气候区时没有定量标准的缺憾 ${ }^{[11]}$, 并于 1979 年采 用 1951 1970 年的资料对区划界线进行了修订, 最终 将全国划分为 10 个气候带(其中青藏高原称“高原气候 区域”)、22 个气候大区、 45 个气候区 ${ }^{[12]}$.

三是 20 世纪 80 年代初以来. 这一阶段, 气候系 统概念正式确立，气候区划的主要目的也不再限于 为农业生产服务, 因而在进行气候区划时也更强调 突出气候区作为一个区域气候系统的相对独立性, 更注重气候要素应与自然景观及其他自然地理特征 的相互吻合. 在这些思想的影响下, 我国学者发现了 以往在区划指标选取上的一些明显不足. 以热量指 标为例, 由于我国地形地势及下垫面对气候形成影 响显著, 且季风气候突出, 因而以往区划采用日平均 气温稳定 $\geqslant 10^{\circ} \mathrm{C}$ 期间的积温作为主要热量指标划分气 候带对指导农业生产布局作用突出 ${ }^{[13,14]}$, 但在许多 地区却无法与自然地带性吻合. 如云贵高原腾冲至 昆明一线的积温与黄淮地区基本相当(均约 $4500^{\circ} \mathrm{C}$ ), 但两地气候却大相径庭, 植被等自然景观也截然不 同, 前者属亚热带景观, 后者却属暖温带, 说明若以 积温为主要热量指标划分气候带存在缺陷. 而通过 对日平均气温稳定 $\geqslant 10^{\circ} \mathrm{C}$ 期间的积温与日数的大量相 关分析、以及气候与自然景观之间的对应关系分析则
发现: 若采用积温日数作为气候带的划分指标，不但 能表现出气候的水平地带性, 也能很好地表现出气 候的垂直地带性 ${ }^{[15]}$. 此后, 又通过对各种指标的不 断尝试, 最终形成了以日平均气温稳定 $\geqslant 10^{\circ} \mathrm{C}$ 的日数 等热量指标划分温度带, 以干燥度等干湿指标划分 干湿区，再根据最热月平均气温指标划分三级气候 区的方法体系 ${ }^{[16]}$. 中央气象局采用这一方法分别编 制了 1951 1980 年和 1961 1990 年的全国气候区划 图 ${ }^{[17,18]}$, 并将其确定为国家标准 ${ }^{[19]}$; 我们也采用该 方法编制了 1971 2000 年的中国气候区划 ${ }^{[20]}$.

然而在全球变化背景下, 我国气候在过去 60 年 中已发生了许多显著变化 ${ }^{[21,22]}$, 如气温在波动中上 升，且北方大于南方、冬季大于夏季; 降水虽无显著 增减趋势，但年代际振荡及区域性的趋势变化明显， 华北、东北东南部、西北东部自 20 世纪 70 年代以后 呈减少趋势，西部及东南地区则呈增加趋势; 同时日 照时数、平均风速、水面蒸发等也呈不同程度下降趋 势 ${ }^{[23,24]}$; 导致了我国许多区域的气候特征出现改变. 虽然已有研究 ${ }^{[25 \sim 31]}$ 分析了过去数十年我国气候带或 干湿状况变化, 特别是单个气候分区指标或气候带、 区划分界线的局部变化，但这些研究并未关注我国 气候区划的整体变化, 且多数研究的资料均截止到 2000 年. 因而更新资料进行全国气候区划不论是对 科学研究, 还是在应用上, 都很有必要 ${ }^{[32]}$; 成为我国 近期气象行业专项等研究计划的一个重要研究内 容 ${ }^{1)}$. 为此, 本文将资料更新至 1981 2010 年, 再次 对我国气候状况进行区划; 同时通过其与 1951 1980 年等早期的区划结果的对比，分析我国 1981 2010年 气候区划的变动特征与原因机理.

\section{1 资料和方法}

\section{1 资料处理}

本文所用的基本资料来自中国 756 个站气象观 测日值数据集(1951 2010 年), 包括日平均气温、最 高气温、最低气温、降水量、平均相对湿度、平均风 速、平均气压及日照时数 8 个要素. 该数据集由各省 上报的全国地面月报信息化文件根据《全国地面气候 资料统计方法》及《地面气象观测规范》有关规定整

1) 2010 2011 年公益性行业(气象)科研专项项目指南, http://www.cma.gov.cn/gg/201003/P02010031553 7572983297.pdf 
编统计而得, 并经严格的数据质量控制、均一性检查 及记录订正与复核; 于 2008 年 4 月 1 日由中国气象 局国家气象信息中心首次发布，然后逐季更新(中国 气象科学数据共享服务网, http://cdc.cma.gov.cn/ home.do). 然而, 部分台站因受迁址及测站类型变更 等因素影响, 使得资料不连续. 为避免其对气候区划 结果的影响, 我们采用文献[33]提出的资料整合与均 一性订正方案和方法, 对上述数据集中因迁址及测 站类型变更而致的日气温资料不连续与不均一问题 进行了订正和整合. 而对降水量、最大可能蒸散等表 征干湿状况的资料整合与均一性订正, 我们虽采用 了与日气温资料订正完全一样的订正方案和步骤, 但采用比值法进行订正 ${ }^{[34]}$. 即先分别检测因测站类 型变更而致的相邻测站年降水量和年最大可能蒸散 量的年际变化一致性及其比值年际变化的稳定性, 然后再分别利用这两个比值, 进行年降水量和年最 大可能蒸散量的整合和均一性订正. 其中年降水量 直接通过统计逐日降水而得. 而对年最大可能蒸散 量, 则是根据各站的日资料, 按文献[35]修正的最大
可能蒸散估算模型, 先计算出逐日最大可能蒸散, 然 后再将其统计为年最大可能蒸散量.

而为保证资料的完整性，我们又对经过上述资 料整合和订正后的数据缺失 10 年及 10 年以上的站点 进行了剔除, 最终得到了 658 个站点(包括 582 个数 据完整的站和 76 个原数据不足 30 年但根据上述方法 订正后的站)的资料(图 1). 由于目前我们没有台湾的 日气象观测数据, 因而用台湾 25 个站的月气候数据 作为辅助资料.

\section{2 区划方法和指标体系}

本文参照国家标准采用的气候区划方法 ${ }^{[19,20]}$ 进 行我国 1981 2010 年的三级气候区划分. 即在遵循 “地带性与非地带性相结合、发生同一性与区域气候 特征相对一致性相结合、综合性和主导因素相结合、 自上而下和自下而上相结合及空间分布连续性与取 大去小”等 5 个原则的基础上，先根据青藏高原和我 国其他区域的自然地域分异特征，将青藏高原划分 为一个独立的自然单元，然后结合两大区域(即青藏

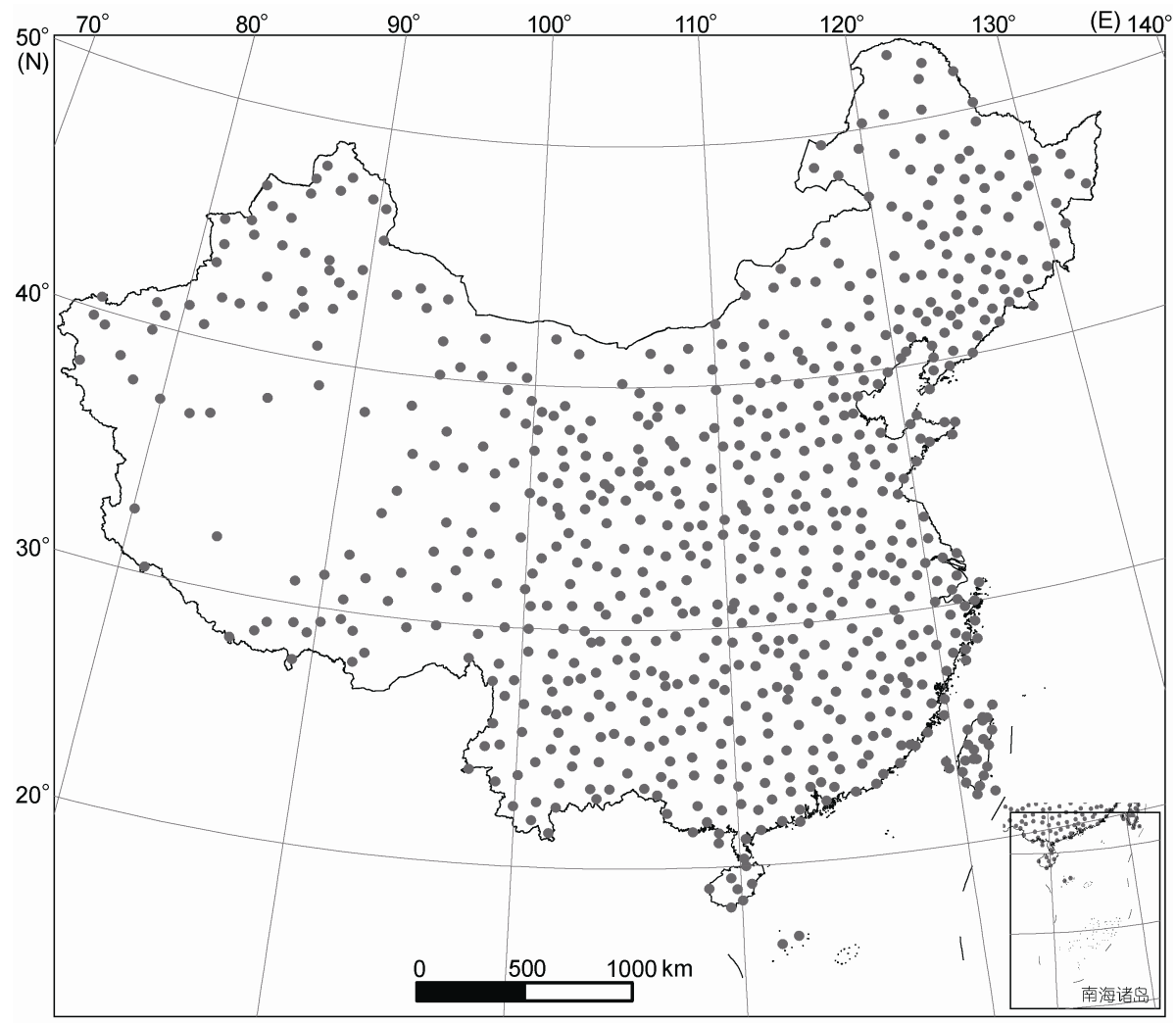

图 1 用于进行中国 1981 2010 年气候区划的气象站点分布 
高原和其他区域)的气候特征，划分温度带、干湿区 和气候区. 其中青藏高原由于站点地理分布不均匀, 且相对稀少, 故不进行第三级气候区的划分. 具体指 标与划分标注如下:

(1) 温度带. 以日平均气温稳定 $\geqslant 10^{\circ} \mathrm{C}$ 的日数作 为划分温度带的主要指标, 以日平均气温稳定 $\geqslant 10^{\circ} \mathrm{C}$ 的积温为参考指标. 同时以 1 月平均气温作为划分温 度带的辅助指标, 以极端最低气温的多年平均值为 其参考指标. 由于青藏高原地势差异大, 气候垂直差 异悬殊, 植物能否良好生长, 不仅取决于其能否越冬, 还取决于生长期间的热量强度, 因此对青藏高原, 我 们还同时将 7 月平均气温作为辅助指标. 各温度带的 具体划分标准见表 1 . 其中, 在同一水平地带中, 云 贵地区(特别是云贵高原)因受地形影响, 因此其温度
带的划分标准较东部低海拔地区低.

(2) 干湿区划分指标. 以年干燥度(最大可能蒸 散多年平均与年降水量多年平均的比值)作为干湿区 划分的主要指标, 以年降水量作为辅助指标. 具体划 分标准见表 2. 其中在计算最大可能蒸散时, 先根据 各站的日资料, 按文献[35]修正的最大可能蒸散估算 模型计算出逐日最大可能蒸散, 然后再将其统计为 年最大可能蒸散量.

(3) 气候区划分指标. 温度带和干湿区划分主 要体现了气候的地带性差异, 然而气候还受非地带 性因素影响. 在我国, 7 月平均气温的地理分布能较 为综合地表现出非地带性因素对气候的影响作 用 ${ }^{[15,16]}$, 因而本区划采用 7 月平均气温作为气候区的 划分指标. 划分标准见表 3.

表 1 划分温度带的指标体系及划分各温度带的标准

\begin{tabular}{|c|c|c|c|c|c|}
\hline \multirow[b]{2}{*}{ 温度带 } & \multirow{2}{*}{$\begin{array}{l}\text { 主要指标 } \\
\text { 日平均气温稳定 } \\
\geqslant 10^{\circ} \mathrm{C} \text { 的日数 }(\mathrm{d})\end{array}$} & \multicolumn{2}{|l|}{ 辅助指标 } & \multicolumn{2}{|c|}{ 参考指标 } \\
\hline & & $\begin{array}{l}1 \text { 月平均 } \\
\text { 气温 }\left({ }^{\circ} \mathrm{C}\right)\end{array}$ & $\begin{array}{l}7 \text { 月平均 } \\
\text { 气温 }\left({ }^{\circ} \mathrm{C}\right)\end{array}$ & $\begin{array}{c}\text { 日平均气温稳定 } \geqslant 10^{\circ} \mathrm{C} \\
\text { 期间的积温 }\left({ }^{\circ} \mathrm{C}\right)\end{array}$ & $\begin{array}{l}\text { 年极端最低气温 } \\
\text { 多年平均值 }\left({ }^{\circ} \mathrm{C}\right)\end{array}$ \\
\hline 寒温带 & $<100$ & $<-30$ & & $<1600$ & $<-44$ \\
\hline 中温带 & $100 \sim 170$ & -30 至 $-12 \sim-6$ & & 1600 至 3200 3400 & $-44 \sim-25$ \\
\hline 暖温带 & $170 \sim 220$ & $-12 \sim-6$ 至 0 & & $3200 \sim 3400$ 至 4500 4800 & $-25 \sim-10$ \\
\hline 北亚热带 & $\begin{array}{c}220 \sim 240 \\
210 \sim 225 \text { (云贵高原) }^{a)}\end{array}$ & $0 \sim 4$ & & $\begin{array}{c}4500 \sim 4800 \text { 至 5100 5300 } \\
3500 \sim 4500 \text { (云贵高原) }\end{array}$ & $-14 \sim-10$ 至-6 -4 \\
\hline 中亚热带 & $\begin{array}{c}240 \sim 285 \\
225 \sim 285 \text { (云贵高原) }\end{array}$ & $4 \sim 10$ & & $\begin{array}{l}5100 \sim 5300 \text { 至 6400 6500 } \\
4000 \text { 至 } 5000 \text { (云贵高原) }\end{array}$ & $\begin{array}{c}-6 \sim-4 \text { 至 } 0 \\
-4 \text { 至 } 0 \text { (云贵高原) }\end{array}$ \\
\hline 南亚热带 & $285 \sim 365$ & $\begin{array}{c}10 \sim 15 \\
9 \sim 10 \text { 至 13 15 (云南高原) }\end{array}$ & & $\begin{array}{c}6400 \sim 6500 \text { 至 } 8000 \\
5000 \text { 至 } 7500 \text { (云南高原) }\end{array}$ & $\begin{array}{c}0 \sim 5 \\
0 \sim 2 \text { (云南高原) }\end{array}$ \\
\hline 边缘热带 & 365 & $\begin{array}{c}15 \sim 18 \\
>13 \sim 15 \text { (云南高原) }\end{array}$ & & $\begin{array}{c}8000 \sim 9000 \\
\text { 7500 8000(云南高原) }\end{array}$ & $\begin{array}{c}5 \sim 8 \\
>2 \text { (云南高原) }\end{array}$ \\
\hline 中热带 & 365 & 18 至 24 & & $9000 \sim 10000$ & $8 \sim 20$ \\
\hline 赤道热带 & 365 & $>24$ & & $>10000$ & $>20$ \\
\hline 高原 b)亚寒带 & $<50$ & -18 至-10 - 12 & $<11$ & & \\
\hline 高原温带 & $50 \sim 180$ & $-10 \sim-12$ 至 0 & $11 \sim 18$ & & \\
\hline 高原亚热带山地 & $180 \sim 350$ & $>0$ & $18 \sim 24$ & & \\
\hline
\end{tabular}

a) 指在云贵高原用该标准划分中亚热带, 其他括号含义同; b) 高原范围根据文献[36]界定的范围划定

表 2 划分干湿区的指标体系及其标准

\begin{tabular}{|c|c|c|c|c|c|c|c|}
\hline \multirow{2}{*}{ 干湿状况 } & \multicolumn{3}{|c|}{ 主要指标 } & \multicolumn{4}{|c|}{ 辅助指标 } \\
\hline & \multicolumn{3}{|c|}{ 年干燥指数 } & \multicolumn{4}{|c|}{ 降水量 $(\mathrm{mm})$} \\
\hline 湿润 & \multicolumn{3}{|c|}{$\geqslant 1.00$} & \multicolumn{4}{|c|}{$>800 \sim 900$ 或>600 650(东北、川西山地) } \\
\hline 半湿润 & \multicolumn{3}{|c|}{$1.00 \sim 1.50$} & \multicolumn{4}{|c|}{ 400 500 至 800 900 或 400 600(东北) } \\
\hline 半干旱 & \multicolumn{3}{|c|}{$1.50 \sim 4.00$ 或 $1.50 \sim 5.00$ (青藏高原) } & \multicolumn{4}{|c|}{ 200 250 至 400 500 } \\
\hline 干旱 & \multicolumn{3}{|c|}{$\geqslant 4.00$ 或 $\geqslant 5.00$ (青藏高原) } & \multicolumn{4}{|c|}{$<200 \sim 250$} \\
\hline \multicolumn{8}{|c|}{ 表 3} \\
\hline 气候区 & $\mathrm{Ta}$ & $\mathrm{Tb}$ & $\mathrm{Tc}$ & $\mathrm{Td}$ & $\mathrm{Te}$ & $\mathrm{Tf}$ & $\mathrm{Tg}$ \\
\hline 7 月平均气温 $\left({ }^{\circ} \mathrm{C}\right)$ & $\leqslant 18$ & $18 \sim 20$ & $20 \sim 22$ & $22 \sim 24$ & $24 \sim 26$ & $26 \sim 28$ & $\geqslant 28$ \\
\hline
\end{tabular}




\section{2 结果}

\section{1 区划指标的地理分布}

图 2 给出全国 658 个站 1981 2010 年各个区划指 标的地理分布. 该图根据三角形线性插值法(Trianglebased linear interpolation)绘制, 空间分辨率为 0.25 经 纬度; 由于地形是影响气候的重要因素之一, 也是进 行气候区划的重要参考依据, 且在我国地形(如秦岭, 第二、三级地形阶梯等)本身就是重要的气候分界线, 因而插值过程未进行地形订正. 这一方法充分尊重 原始观测数据, 与人工绘制等值线方法一致, 从而保 证了其与以往区划结果的可比性.

图 2 显示, 除青藏高原外, 我国其他地区日平均 气温稳定 $\geqslant 10^{\circ} \mathrm{C}$ 的日数 (下简称 “ $\geqslant 10^{\circ} \mathrm{C}$ 日数”) 与积温 (图 2(a), (b))基本呈纬向分布, 自南向北逐渐减小. 其中, 最南的南海岛屿、海南、雷州半岛及云南南部 边缘的瑞丽江、怒江、澜沧江、元江河谷等地的日平 均气温全年稳定 $\geqslant 10^{\circ} \mathrm{C}$, 积温超过 $8000^{\circ} \mathrm{C}$. 南岭以南 至云南南部及金沙江河谷 $\geqslant 10^{\circ} \mathrm{C}$ 日数及积温大多超过 $285 \mathrm{~d}$, 积温超过 $6000^{\circ} \mathrm{C}$. 江南丘陵山地、江汉平原、 四川盆地 $\geqslant 10^{\circ} \mathrm{C}$ 日数大多超过 $240 \mathrm{~d}$, 积温超过 $5000^{\circ} \mathrm{C}$; 贵州、滇东、中高原及横断山南段山地虽因 地形影响, 气候垂直差异大, 但其中大多数地区 $\geqslant 10^{\circ} \mathrm{C}$ 日数达 $225 \mathrm{~d}$ 以上, 积温超过 $4000^{\circ} \mathrm{C}$. 江淮平 原、河南南部及秦巴山地 $\geqslant 10^{\circ} \mathrm{C}$ 日数大多超过 $220 \mathrm{~d}$, 积温达 $4500^{\circ} \mathrm{C}$ 以上; 黔西北、川西南、滇北高原虽然 海拔较高, 但这些地区 $\geqslant 10^{\circ} \mathrm{C}$ 日数及积温大多仍达 $210 \mathrm{~d}$ 和 $3500^{\circ} \mathrm{C}$ 以上. 辽东半岛、燕山低山丘陵与华 北平原、太行山地、山西高原和黄土高原东部及其以 南山地、吐鲁番盆地及南疆等地的 $\geqslant 10^{\circ} \mathrm{C}$ 日数及积温 分别超过 $170 \mathrm{~d}$ 和 $3200^{\circ} \mathrm{C}$. 东北、内蒙大部、宁夏北 部、河西走廊及北疆地区 $\geqslant 10^{\circ} \mathrm{C}$ 日数及积温分别超过 $100 \mathrm{~d}$ 和 $1600^{\circ} \mathrm{C}$. 而我国最北的大兴安岭北部虽然海 拔 $500 \mathrm{~m}$ 以下谷地的全年日平均气温 $\geqslant 10^{\circ} \mathrm{C}$ 日数及积 温可分别达 $100 \mathrm{~d}$ 与 $1600^{\circ} \mathrm{C}$ 以上, 但因这里海拔大多 在 $500 \mathrm{~m}$ 以上, 因而大多数地区全年日平均气温 $\geqslant 10^{\circ} \mathrm{C}$ 日数低于 $100 \mathrm{~d}$, 积温低于 $1600^{\circ} \mathrm{C}$.

受地形影响, 青藏高原 $\geqslant 10^{\circ} \mathrm{C}$ 日数及积温主要随 地势而变化. 其中昆仑山、唐古拉山、冈底斯山、念 青唐古拉山西段及若尔盖高原地区的 $\geqslant 10^{\circ} \mathrm{C}$ 日数多在 $50 \mathrm{~d}$ 以下; 环绕这些高山的外围亚高海拔山地 $\geqslant 10^{\circ} \mathrm{C}$
日数一般均在 $50 \mathrm{~d}$ 以上, 其中大部分谷地(如藏南、 藏东南谷地)可超过 $130 \mathrm{~d}$, 有些海拔相对较低的河谷 甚至可接近 $180 \mathrm{~d}$. 而喜马拉雅山南翼至横断山的西 南缘山地, 虽然垂直高差大, 但这里峡谷深切, 因而 谷地的海拔多在 $2500 \mathrm{~m}$ 以下, 故这些地区 $\geqslant 10^{\circ} \mathrm{C}$ 日数 一般达 $180 \mathrm{~d}$ 以上.

我国 1 月平均气温(图 2(c)) 与年极端最低气温多 年平均值(图 2(d)) 的地理分布特征与 $\geqslant 10^{\circ} \mathrm{C}$ 日数的空 间格局及走势基本一致, 即除青藏高原外的其他地 区基本呈自南向北逐渐减小的纬向分布, 青藏高原 则随地势呈环岛状分布. 其中南端的雷州半岛及其 以南地区和台湾南部及云南南部边缘河谷地区的 1 月平均气温与年极端最低气温多年平均值分别达 15 和 $5^{\circ} \mathrm{C}$ 以上; 而北端的图里河、漠河等地则分别接近 -30 和 $-45^{\circ} \mathrm{C}$. 青藏高原大部分地区 1 月平均气温与 年极端最低气温多年平均值分别在 0 和 $-10^{\circ} \mathrm{C}$ 以下 (其中大多数高海拔山地更是分别达 -10 和 $-20^{\circ} \mathrm{C}$ 以 下), 仅喜马拉雅山南翼至横断山的西南缘河谷地区 的 1 月平均气温可达 $0^{\circ} \mathrm{C}$ 以上.

我国年干燥度(图 2(e))总体上自东南向西北增加, 年降水量(图 2(f)) 则自东南向西北逐渐减小. 其中, 东北的大兴安北部、小兴安岭与长白山的干燥度小于 1.0 , 除此之外其他地区的干燥度则多为 $1.0 \sim 1.5$. 黄 淮海地区、山西南部、陕西中部、甘肃南部及青藏高 原东南部的干燥度多为 1.0 1.5, 其中京津及河北平 原中北部的干燥度虽然大于 1.5 , 但多低于 1.7 , 且多 数地区的降水量达 $550 \sim 650 \mathrm{~mm}$; 而这一地带的以 东、以南地区的干燥度则通常在 1.0 以下. 内蒙东部、 河北西北部、陕西北部、山西北部、宁夏中南部、甘 肃中部至青藏高原中部一带的干燥度一般为 1.5 4.0; 而其以西、以北地区干燥度大多为 4.0 以上, 仅新疆 的天山山地、伊犁河谷、阿尔泰山地及塔城盆地干燥 度在 4.0 以下.

我国 7 月平均气温虽总体也呈南高北低、东高西 低分布, 但地带性特征不显著、南北差异不大(图 $2(\mathrm{~g}))$. 其中在东部, 东北地区的大、小兴安岭北部为 $20^{\circ} \mathrm{C}$ 以下, 其他地区多为 $20 \sim 24^{\circ} \mathrm{C}$; 内部东部、太行 山地及黄土高原地区也多为 $20 \sim 24^{\circ} \mathrm{C}$; 东北南部、山 东半岛及秦岭山地多为 $24 \sim 26^{\circ} \mathrm{C}$; 黄淮海、汾渭平原、 四川盆地、湘鄂西山地为 $26 \sim 28^{\circ} \mathrm{C}$; 长江以南一般在 $28^{\circ} \mathrm{C}$ 以上. 在西部, 7 月平均气温主要受地势高低影 响, 其中海拔较低的准噶尔盆地、塔里木盆地和吐鲁 


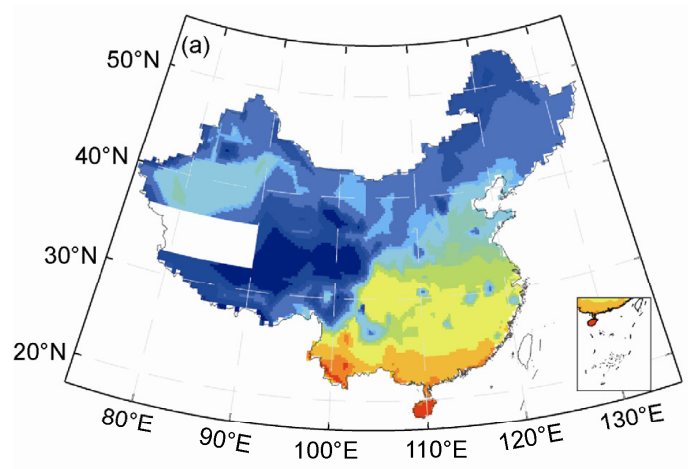

50100130170180210220225240285350365 (d)
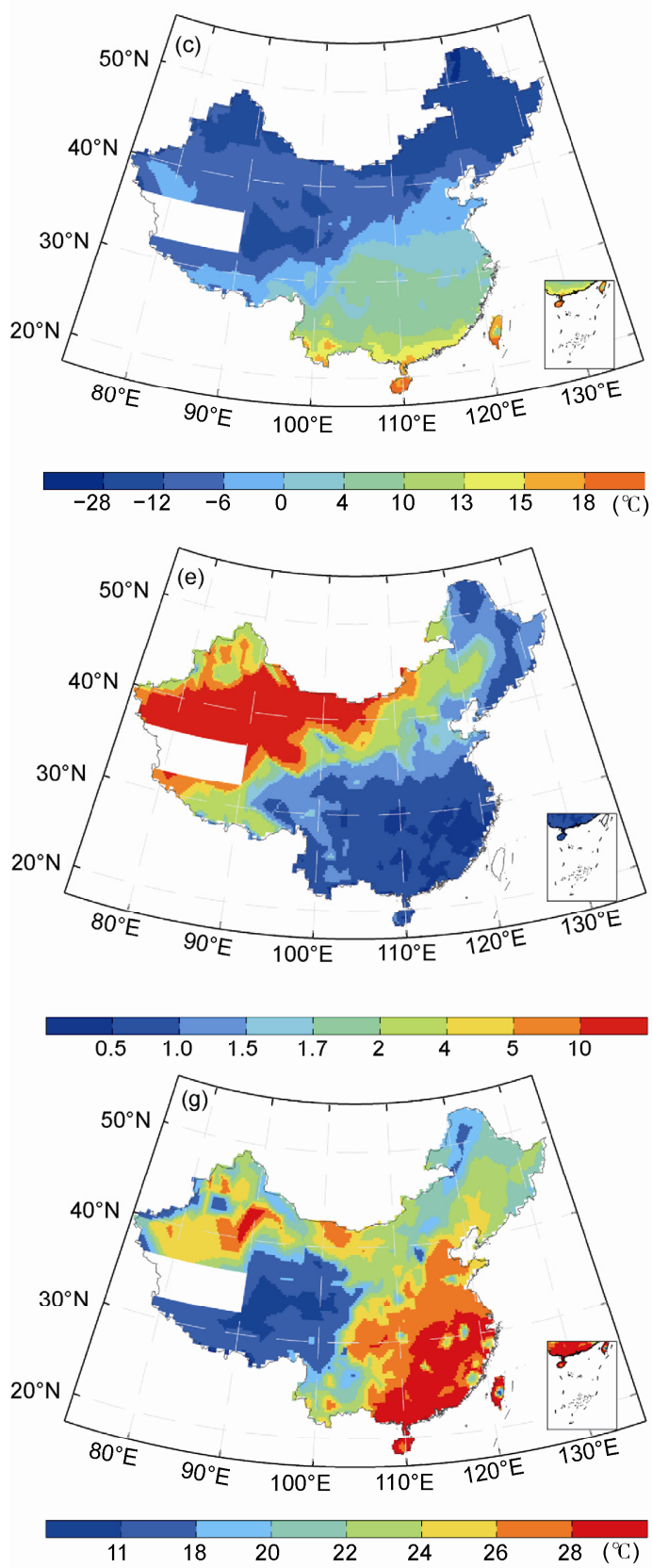
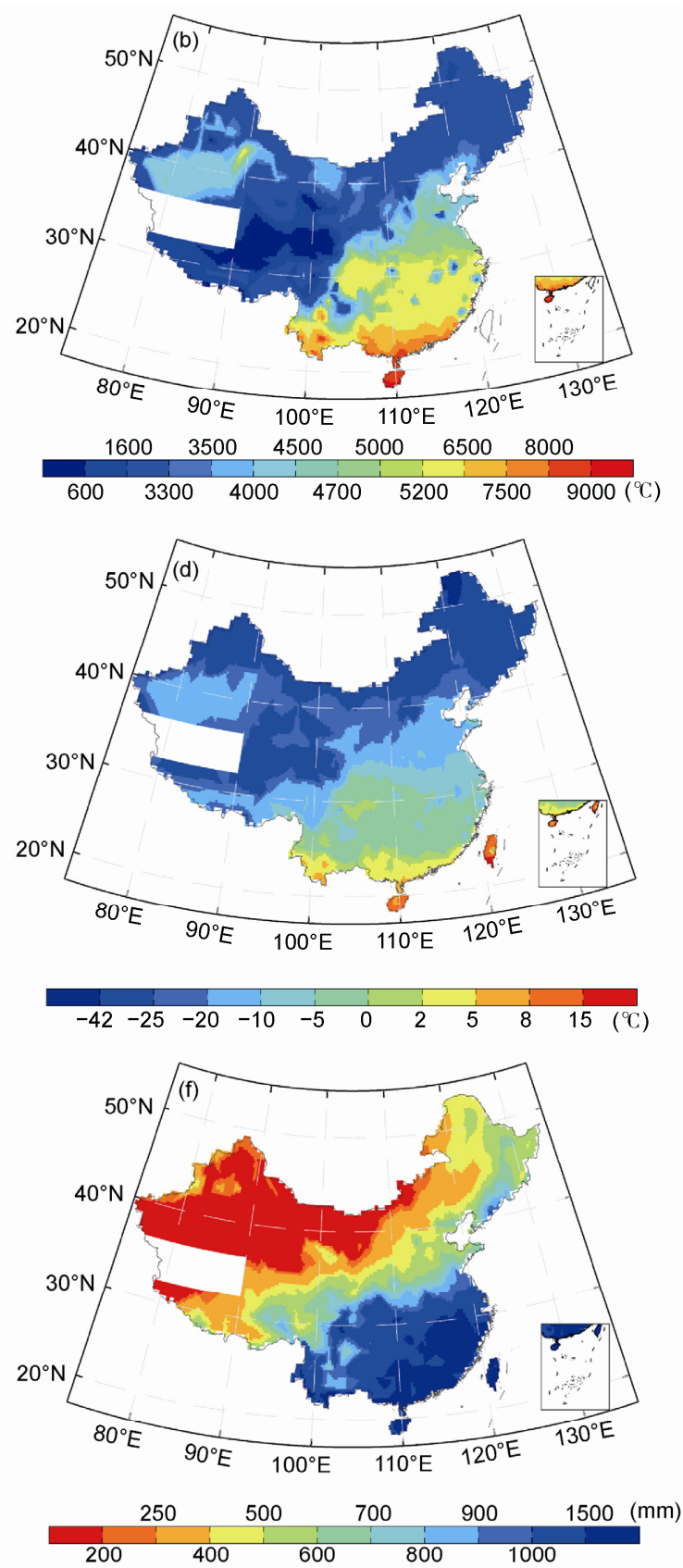

图 $21981 \sim 2010$ 年中国气候区划主要指标的 地理分布

(a) 日平均气温稳定 $\geqslant 10^{\circ} \mathrm{C}$ 日数，(b) 日平均气温 稳定 $\geqslant 10^{\circ} \mathrm{C}$ 积温, (c) 1 月平均气温, (d) 年极端最 低气温多年平均值, (e) 年干燥度, (f) 年降水量,

(g) 7 月平均气温 
番盆地均超过 $24^{\circ} \mathrm{C}$, 较东部同纬度地区高, 吐鲁番 盆地更高达到 $32^{\circ} \mathrm{C}$ 以上; 而除此之外的高原和山区 一般在 $20^{\circ} \mathrm{C}$ 以下，仅云贵高原可达 $20 \sim 24^{\circ} \mathrm{C}$. 青藏高 原大部分地区为 $16^{\circ} \mathrm{C}$ 以下, 部分高海拔地区甚至在 $10^{\circ} \mathrm{C}$ 以下.

\section{2 区划结果}

根据上述区划原则、方法和 1981 2010 年各站的 气候指标值及各指标的地理分布特征, 将我国划分 为 12 个温度带、 24 个干湿区、56 个气候区(图 3); 各 区的位置及代表站的气候指标值见表 4. 其中在利用 各指标体系划分温度带和干湿区时, 均分别先以各 站的主要指标值为依据进行划分. 当因主要指标值 差异较小而不能明确指示该站所属区域，或因一些
站点受地形及非地带性因素影响而致该地带内少数 站点的主要指标值与多数站点差异较大时, 则以辅 助指标进行区域划分. 当主要及辅助指标统计结果 空缺或据主要及辅助指标仍无法进行区域界线划分 时，则以参考指标作为依据确定界线. 而在划定区划 界线时, 则主要依据指标的等值线确定界线走向; 并 根据空间分布连续性与取大去小原则，在保证区域 气候特征相对一致性基础上, 参照地形(如山麓、分 水岭等)划定界线的具体位置.

\section{3 本区划较 1971 2000 年区划的改进}

与笔者先前编制的 1971 2000 年气候区划 ${ }^{[20]}$ 相 比，本区划共使用了 658 个站的资料, 较当时 609 个 增加了 49 个, 因这些增加的站点主要分布在我国西

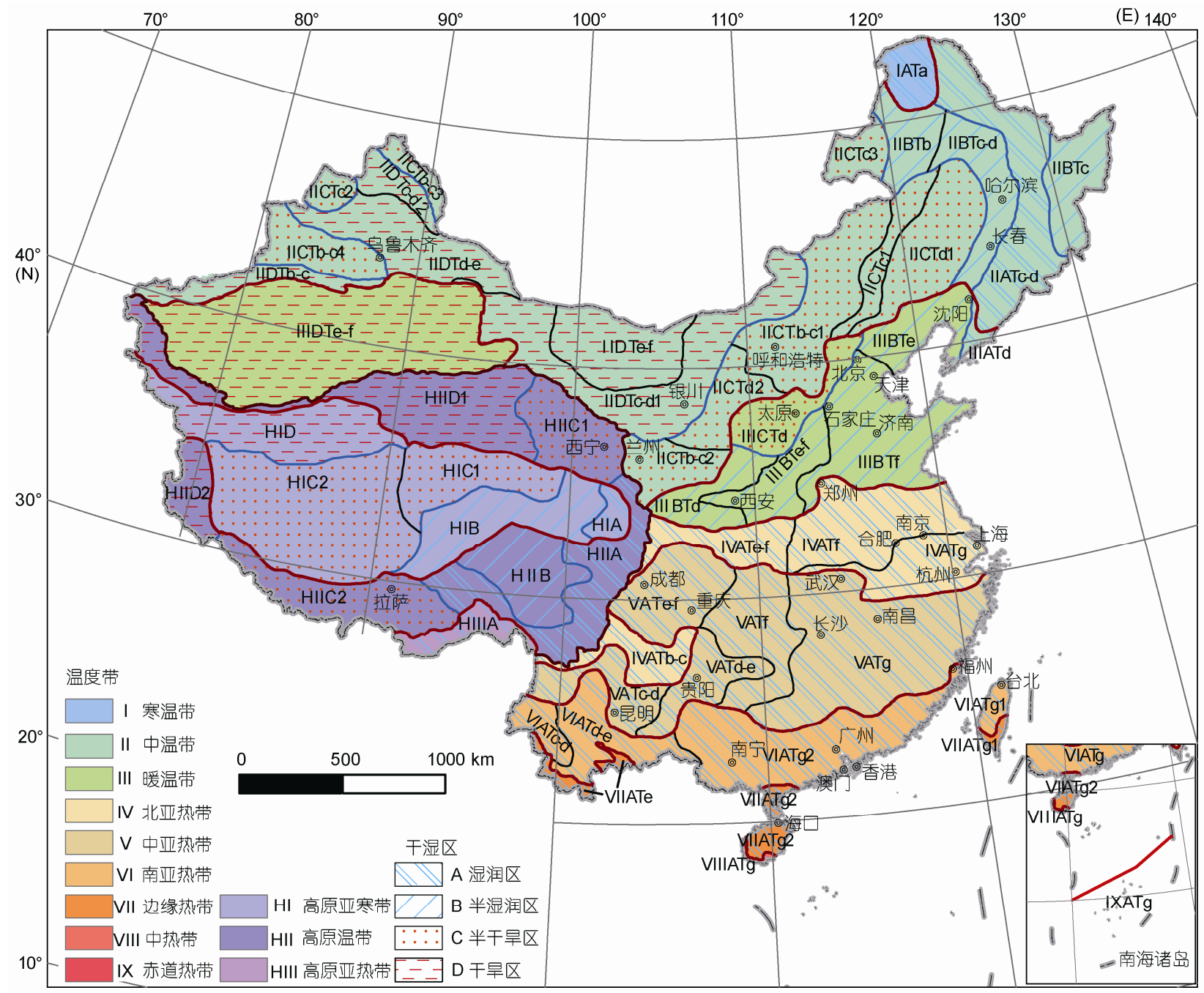

图 3 1981 2010 年中国气候区划简图 
表 4 中国 1981 2010 年的气候区划结果

\begin{tabular}{|c|c|c|c|c|c|c|c|c|c|c|c|}
\hline \multirow[b]{2}{*}{ 温度带 } & \multirow[b]{2}{*}{ 干湿区 } & \multirow[b]{2}{*}{$\begin{array}{l}\text { 气候区 } \\
\text { 代码 }\end{array}$} & \multirow[b]{2}{*}{ 所在位置 } & \multicolumn{8}{|c|}{ 代表站点及其海拔高度与主要、辅助气候指标值 } \\
\hline & & & & 站点名称 & 编号 & $\begin{array}{c}\text { 海拔 } \\
(\mathrm{m})\end{array}$ & $\begin{array}{l}\geqslant 10^{\circ} \mathrm{C} \\
\text { 日数 }(d)\end{array}$ & $\begin{array}{l}1 \text { 月气 } \\
\text { 温 }\left({ }^{\circ} \mathrm{C}\right)\end{array}$ & $\begin{array}{l}7 \text { 月气 } \\
\text { 温 }\left({ }^{\circ} \mathrm{C}\right)\end{array}$ & $\begin{array}{l}\text { 年干 } \\
\text { 燥度 }\end{array}$ & $\begin{array}{l}\text { 年降水 } \\
\text { 量 }(\mathrm{mm})\end{array}$ \\
\hline 寒温带 & 湿润区 & IATa & 大兴安岭北部 & 图里河 & 50434 & 732.6 & 93 & -28.4 & 16.8 & 1.0 & 440 \\
\hline \multirow{20}{*}{ 中温带 } & 湿润区 & IIATc-d & 小兴安岭与长白山 & 伊春 & 50774 & 240.9 & 126 & -21.3 & 20.9 & 0.8 & 626 \\
\hline & \multirow{3}{*}{ 半湿润区 } & IIBTc & 三江平原及其以南山地 & 宝清 & 50888 & 83.0 & 147 & -16.8 & 22.2 & 1.4 & 491 \\
\hline & & IIBTc-d & 松辽平原 & 长春 & 54161 & 236.8 & 158 & -14.7 & 23.2 & 1.3 & 577 \\
\hline & & $\mathrm{IIBTb}$ & 大兴安岭中部 & $\begin{array}{l}\text { 额尔古纳 } \\
\text { 右旗 }\end{array}$ & 50425 & 581.4 & 113 & -27.8 & 19.6 & 1.4 & 361 \\
\hline & \multirow{10}{*}{ 半干旱区 } & IICTd1 & 西辽河平原 & 赤峰 & 54218 & 568.0 & 164 & -10.4 & 23.7 & 2.2 & 370 \\
\hline & & IICTc1 & 大兴安岭南部 & 林西 & 54115 & 799.5 & 144 & -13.5 & 21.6 & 2.0 & 369 \\
\hline & & $\mathrm{IICTb}-\mathrm{c} 1$ & 呼伦贝尔平原 & 海拉尔 & 50527 & 610.2 & 119 & -24.8 & 20.4 & 1.7 & 352 \\
\hline & & $\mathrm{IICTb}-\mathrm{c} 2$ & 内蒙古高原东部 & 锡林浩特 & 54102 & 1003 & 131 & -18.8 & 21.6 & 3.1 & 264 \\
\hline & & IICTd2 & 鄂尔多斯高原与东河套 & 呼和浩特 & 53463 & 1063.0 & 160 & -11.0 & 23.3 & 1.8 & 396 \\
\hline & & $\mathrm{IICTb}-\mathrm{c} 3$ & 黄土高原西部 & 海源 & 53806 & 1854 & 148 & -6.2 & 20.3 & 2.4 & 359 \\
\hline & & $\mathrm{IICTb}-\mathrm{c}$ & 阿尔泰山地 & 青河 & 51186 & 1218 & 124 & -21.5 & 19.6 & 3.1 & 189 \\
\hline & & $\mathrm{IICTc} 2$ & 塔城盆地 & 塔城 & 51133 & 534.9 & 158 & -9.7 & 23.1 & 2.7 & 291 \\
\hline & & \multirow{2}{*}{$\mathrm{IICTb}-\mathrm{c} 4$} & \multirow{2}{*}{ 天山天地与伊犁谷地 } & 乌鲁木齐 & 51463 & 935 & 157 & -12.1 & 23.8 & 2.8 & 299 \\
\hline & & & & 伊宁 & 51431 & 662.5 & 180 & -7.8 & 23.3 & 2.4 & 299 \\
\hline & \multirow{6}{*}{ 干旱区 } & \multirow{2}{*}{ IIDTc-d1 } & \multirow{2}{*}{$\begin{array}{c}\text { 内蒙古高原西部、西河套 } \\
\text { 与河西走廊 }\end{array}$} & 银川 & 53614 & 1111.4 & 178 & -7.2 & 23.9 & 4.6 & 183 \\
\hline & & & & 张掖 & 52652 & 1482.7 & 163 & -9.1 & 22.3 & 6.1 & 133 \\
\hline & & IIDTe-f & 巴丹吉林与腾格里沙漠 & 额济纳旗 & 52267 & 940.5 & 176 & -10.6 & 27.5 & 34.2 & 33 \\
\hline & & IIDTd-e & 准噶尔盆地 & 奇台 & 51379 & 793.5 & 152 & -17.0 & 22.7 & 4.2 & 201 \\
\hline & & IIDTc-d2 & 萨吾尔山、额尔齐斯谷地 & 福海 & 51068 & 501 & 154 & -18.6 & 23.4 & 5.6 & 131 \\
\hline & & IIDTb-c & 天山南麓 & 阿克苏 & 51628 & 1103.8 & 196 & -7.2 & 24.1 & 9.8 & 80 \\
\hline \multirow{7}{*}{ 暖温带 } & \multirow[t]{2}{*}{ 湿润区 } & IIIATd & 辽东低山丘陵 & 庄河 & 54584 & 34.8 & 181 & -7.3 & 23.2 & 0.9 & 736 \\
\hline & & IIIBTe & 燕山低山丘陵与辽东半岛 & 锦州 & 54337 & 65.9 & 188 & -7.6 & 24.6 & 1.4 & 568 \\
\hline & \multirow{3}{*}{ 半湿润区 } & IIIBTf & 华北平原与山东半岛 & 济南 & 54823 & 170.3 & 222 & -0.3 & 27.5 & 1.5 & 693 \\
\hline & & IIIBTe-f & 汾渭平原山地 & 西安 & 57036 & 397.5 & 219 & 0.3 & 27.1 & 1.3 & 561 \\
\hline & & IIIBTd & 黄土高原南部 & 铜川 & 53947 & 978.9 & 181 & -2.8 & 23.3 & 1.4 & 568 \\
\hline & 半干旱区 & IIICTd & 黄土高原东部与太行山地 & 太原 & 53772 & 778.3 & 186 & -5.0 & 24.0 & 1.8 & 423 \\
\hline & 干旱区 & IIIDTe-f & 塔里木与东疆盆地 & 敦煌 & 52418 & 1139 & 179 & -7.9 & 25.2 & 22.5 & 40 \\
\hline \multirow{6}{*}{ 北亚热带 } & \multirow{6}{*}{ 湿润区 } & IVATf & 大别山与苏北平原 & 信阳 & 57297 & 114.5 & 227 & 2.4 & 27.3 & 0.7 & 1106 \\
\hline & & IVATg & 长江下游平原 & 芜湖 & 58334 & 14.8 & 238 & 3.4 & 28.7 & 0.7 & 1225 \\
\hline & & IVATe-f & 秦巴山地 & 安康 & 57245 & 290.8 & 236 & 3.7 & 27.0 & 0.9 & 824 \\
\hline & & & & 黔西 & 57803 & 1231.4 & 223 & 3.8 & 23.1 & 0.6 & 944 \\
\hline & & IVATb-c & 黔西北、川西南、滇北高原 & 越西 & 56475 & 1659.5 & 212 & 4.0 & 21.1 & 0.6 & 1115 \\
\hline & & & & 丽江 & 56651 & 2392.4 & 223 & 6.4 & 18.2 & 1.0 & 980 \\
\hline \multirow{6}{*}{ 中亚热带 } & \multirow{6}{*}{ 湿润区 } & VATg & 江汉平原及江南丘陵 & 南昌 & 58606 & 46.9 & 250 & 5.5 & 29.5 & 0.5 & 1613 \\
\hline & & VATf & 湘鄂西山地 & 沅陵 & 57655 & 151.6 & 243 & 5.1 & 27.6 & 0.5 & 1385 \\
\hline & & VATd-e & 贵州高原山地 & 兴义 & 57902 & 1378.5 & 245 & 6.5 & 22.2 & 0.6 & 1322 \\
\hline & & VATe-f & 四川盆地及其东南山地 & 成都 & 56294 & 506.1 & 256 & 5.9 & 25.6 & 0.7 & 834 \\
\hline & & $\mathrm{VAT} \rho \mathrm{T}$ & 淔东 中心地及横断山南段山地 & 会理 & 56671 & 1787.3 & 265 & 7.3 & 20.9 & 0.7 & 1162 \\
\hline & & VAIC-d & 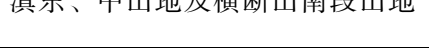 & 华坪 & 56664 & 1244.8 & 345 & 11.8 & 24.3 & 1.0 & 1088 \\
\hline & & VIATg1 & 台湾北部山地平原 & 台北 & & & & 16.1 & 29.6 & & \\
\hline 南亚势带 & & VIATg2 & 闽奥桂低山平原 & 广州 & 59287 & 41.0 & 330 & 13.9 & 28.9 & 0.5 & 1801 \\
\hline 珜业然市 & 桠行区 & VIATd-e & 滇中南山地及金沙江谷地 & 景东 & 56856 & 1162 & 348 & 11.6 & 23.6 & 0.7 & 1154 \\
\hline & & VIATc-d & 滇西南山地 & 临沧 & 56951 & 1502.4 & 349 & 11.7 & 21.7 & 0.7 & 1149 \\
\hline
\end{tabular}


(续表 4)

\begin{tabular}{|c|c|c|c|c|c|c|c|c|c|c|c|}
\hline \multirow[b]{2}{*}{ 温度带 } & \multirow[b]{2}{*}{ 干湿区 } & \multirow{2}{*}{$\begin{array}{l}\text { 气候区 } \\
\text { 代码 }\end{array}$} & \multirow[b]{2}{*}{ 所在位置 } & \multicolumn{8}{|c|}{ 代表站点及其海拔高度与主要、辅助气候指标值 } \\
\hline & & & & 站点名称 & 编号 & $\begin{array}{c}\text { 海拔 } \\
(\mathrm{m})\end{array}$ & $\begin{array}{l}\geqslant 10^{\circ} \mathrm{C} \\
\text { 日数 }(\mathrm{d})\end{array}$ & $\begin{array}{l}1 \text { 月气 } \\
\text { 温 }\left({ }^{\circ} \mathrm{C}\right)\end{array}$ & $\begin{array}{l}7 \text { 月气 } \\
\text { 温 }\left({ }^{\circ} \mathrm{C}\right)\end{array}$ & $\begin{array}{l}\text { 年干 } \\
\text { 燥度 }\end{array}$ & $\begin{array}{l}\text { 年降水 } \\
\text { 量 }(\mathrm{mm})\end{array}$ \\
\hline \multirow{3}{*}{ 边缘热带 } & \multirow{3}{*}{ 湿润区 } & VIIATg1 & 台湾南部山地平原 & $\begin{array}{ll}\text { 恒春 } \\
\end{array}$ & & & & 20.7 & 28.4 & & 2022 \\
\hline & & VIIATg2 & 琼雷低山丘陵 & 海口 & 59758 & 63.5 & 363 & 18.0 & 28.8 & 0.6 & 1697 \\
\hline & & VIIATe & 滇南山地 & 础腊 & 56969 & 631.9 & 365 & 16.5 & 25.0 & 0.6 & 1513 \\
\hline 中热带 & 湿润区 & VIIIATg & 琼南低地与东、中、西沙诸岛 & 三亚 & 59948 & 6.0 & 365 & 21.7 & 28.6 & 0.8 & 1453 \\
\hline 赤道热带 & 湿润区 & IXATg & 南沙群岛 & \multicolumn{8}{|c|}{ 缺资料 } \\
\hline \multirow{5}{*}{ 高原亚寒带 } & 湿润区 & HIA & 若尔盖高原 & 若尔盖 & 56079 & 3439.6 & 26 & -9.6 & 11.2 & 0.9 & 643 \\
\hline & 半湿润区 & HIB & 果洛那曲高山谷地 & 达日 & 56046 & 3967.0 & 14 & -12.0 & 9.8 & 1.1 & 558 \\
\hline & & HIC1 & 青南高原 & 五道梁 & 52908 & 4612.0 & 1 & -16.2 & 6.0 & 2.0 & 302 \\
\hline & & $\mathrm{HIC} 2$ & 㒸塘高原 & 申扎 & 55472 & 4672.0 & 15 & -9.4 & 10.0 & 2.6 & 325 \\
\hline & 干旱区 & HID & 昆仑山高原 & \multicolumn{8}{|c|}{ 缺资料 } \\
\hline \multirow{6}{*}{ 高原温带 } & 湿润区 & HIIA & 横断山脉东、南部 & 康定 & 56374 & 2615.7 & 115 & -1.9 & 15.7 & 0.7 & 858 \\
\hline & 半湿润区 & HIIB & 横断山脉中、北部 & 昌都 & 56137 & 3306.0 & 135 & -1.6 & 16.3 & 1.4 & 489 \\
\hline & \multirow{2}{*}{ 半干旱区 } & HIIC1 & 祁连青东高山盆地 & 西宁 & 52866 & 2295.2 & 140 & -7.3 & 17.4 & 1.6 & 398 \\
\hline & & HIIC2 & 藏南高山谷地 & 拉萨 & 55591 & 3648.9 & 158 & -0.6 & 16.2 & 2.0 & 439 \\
\hline & \multirow{2}{*}{ 干旱区 } & HIID1 & 柴达木盆地与昆仑山北翼 & 大柴旦 & 52713 & 3173.2 & 95 & -12.6 & 16.2 & 8.2 & 93 \\
\hline & & HIID2 & 阿里山地高原 & 狮泉河 & 55228 & 4278.6 & 85 & -12.0 & 14.4 & 13.4 & 66 \\
\hline 高原亚热带 & 湿润区 & HIIIA & $\begin{array}{l}\text { 东喜马拉雅山南翼至 } \\
\text { 横断山西南缘山地 }\end{array}$ & 察隅 & 56434 & 2327.6 & 193 & 4.7 & 19.0 & 0.9 & 792 \\
\hline
\end{tabular}

北和西南地区，提高了本次区划在西部的测站密度， 因而本区划在划分气候区时进行了 3 处改进: 一是位 于内蒙古中西部、宁夏北部及甘肃北部的中温带干旱 区. 1971 2000 年的方案将其划为西河套与内蒙古高 原西部(IIDTd-e)和阿拉善与河西走廊(IIDTc-d)2 个气 候区，但本文根据更多站点的资料将其划分内蒙古 高原西部、西河套与河西走廊(IIDTc-d)和巴丹吉林与 腾格里沙漠(IIDTd-e) 2 个气候区.

二是新疆的天山山地. 1971 2000 年的方案将其 划为中温带干旱区(IIDTb-c), 但这一地区的大多数 站点的年降水均超过 $200 \mathrm{~mm}$, 特别是天山北坡的多 数站点更是达到 $400 \mathrm{~mm}$ 以上, 且大多数站的干燥度 低于 4.0. 所以本文将其与伊犁谷地合并划为中温带 半干旱区(IICTb-c).

三是云贵高原. 由于这一区域山谷相间, 地形复 杂, 海拔高差大, 气候垂直地带性明显, 素有“一山 分四季、十里不同天”之说，因此对这一地区的历次 气候区划均有争议. 我们在 1971 2000年的气候区划 方案中, 剔除了部分与该区域平均海拔相差较大高 山和河谷气象站, 据此将黔西北、川西南高原和滇北 高原东段划为中亚热带湿润区(VATb-c), 将滇北高
原西段与滇中高原合划为另一个中亚热带湿润区 (VATc-d). 而本文的新增站点资料表明：黔西北、川 西南高原和整个滇北高原的气候垂直地带性均极显 著, 其中部分亚高海拔(2000 4000 m)地区具有温带 气候特征. 但从总体看, 这里主要为中海拔(1000 $2000 \mathrm{~m}$ )山地, 区内 $\geqslant 10^{\circ} \mathrm{C}$ 日数为 $210 \sim 225 \mathrm{~d}$, 积温为 $3600 \sim 4300^{\circ} \mathrm{C}$. 由于地形独特, 冬季对冷空气具有显 著阻挡作用, 因而这一地带具有冬暖(其中 1 月气温 达 $4.0^{\circ} \mathrm{C}$ 左右, 较同纬度地区高)春早、夏温不高(其中 7 月气温多为 $20^{\circ} \mathrm{C}$ 上下, 较同纬度地区低)的特点, 多数亚热带作物和果蔬均能安全越冬且能良好生长, 故本文将其划为北亚热带湿润区(IVATb-c). 滇东、 川南及横断山南段山地的气候虽与滇北高原一样具 有显著的垂直地带性, 但大多数站点 $\geqslant 10^{\circ} \mathrm{C}$ 日数达 $250 \mathrm{~d}$ 以上、河谷地区为 $280 \mathrm{~d}$ 左右, 且夏季气温较滇 北高原明显要高, 故本文将其划为中亚热带湿润区 (IVATc-d). 而滇中山地 $\geqslant 10^{\circ} \mathrm{C}$ 日数多为 $285 \mathrm{~d}$ 以上, 特 别是金沙江河谷地区 (如元谋、华坪、仁和等站) $\geqslant 10^{\circ} \mathrm{C}$ 日数更是高达 $340 \mathrm{~d}$ 以上, 因而将其划分为南亚热带 (VIATd-e). 


\section{3 简要讨论}

\section{1 与先前区划结果的对比及区划变化的原因与 机理}

在先前研究中, 我们曾简要对比了我国 1971 2000 年气候区划与 1980 年之前气候区划结果的异同, 发现 1971 2000 年我国的亚热带北界与暖温带北界 东段虽出现了一定程度北移, 北方地区的半湿润与 半干旱分界线也出现了不同程度的东移与南扩, 但 当时温度带与干湿区的总体格局较先前并未发生明 显变化 ${ }^{[20]}$. 然而对比本区划与 1951 1980 年的区划 ${ }^{[17]}$ 可以看出：1981 2010 年我国东部的温度带已出现了 整体性北移. 其中暖温带北界东段最大北移幅度已 超过 1 个纬度; 北亚热带北界东段平均北移 1 个纬度 以上, 并明显越过淮河一线, 这较 1971 2000 年时 ${ }^{[20]}$ 又北移了约 0.5 个纬度, 也较早先研究给出的 $0.5 \sim 1$ 个纬度北移幅度 ${ }^{[25,26]}$ 更为显著. 特别是中亚热带北 界中段从洞庭湖平原移至汉江平原地区南部, 最大 移动幅度达 2 个纬度; 南亚热带北界西段也北移 0.5 2.0 个纬度, 均是 1971 2000 年区划 ${ }^{[20]}$ 所没有的. 而在西部, 虽因受地形影响, 温度带水平移动不显著, 但也可看出: 在青藏高原, 出现了亚寒带范围缩小、 温带范围扩大趋势.

由于本区划的温度带划分方法和指标与先前区 划一致, 因此说明: 1981 2010 年我国东部温度带的 整体性北移和西部高海拔地区温度带的趋势性上升 主要是因我国在 20 世纪 80 年代之后气候变化(特别 是温度显著升温)而致. 进一步对比中国气候变化已 有研究结果的评估可知: 1951 2009 年, 我国平均气 温上升了 $1.38^{\circ} \mathrm{C}$, 平均速率达 $0.23^{\circ} \mathrm{C} / 10$ a; 其中 1951 1984 年升温趋势弱, 快速增暖阶段主要出现在 1985 年以后, 而 2001 2010 年则是自 1951 年以来最 暖的 10 年. 然而其间的增暖却存在较显著的季节与 区域差异. 其中从季节变化看, 冬季最为显著, 春季 次之, 秋季较春季略小, 夏季最小. 从区域差异看, 则是北方增暖大于南方, 特别是最显著的升温区域 主要在 $34^{\circ} \mathrm{N}$ 以北, 且这些地区的增暖速率自 1977 年 起就开始加快 ${ }^{[22]}$; 因此在 1971 2000 年的区划中即 可见暖温带和北亚热带北界出现了北移. 但 1985 年 以后，在我国北方地区继续增暖的同时，其他地区 (特别是南方)也出现了快速增暖趋势, 特别是冬、春、 秋 3 季的增暖幅度更为明显 ${ }^{[23]}$, 这导致了我国 1981
2010 年的中亚热带和南亚热带北界也出现了较大幅 度北移.

其机理是气候变暖, 特别是冬、春、秋季节的大 幅度增暖导致春、秋季日平均气温稳定达到 $10^{\circ} \mathrm{C}$ 的 日期提前与推迟, 使日平均气温稳定 $\geqslant 10^{\circ} \mathrm{C}$ 的日数延 长、积温增加; 且冬季气温升高也同时使 1 月平均气 温及年极端最低气温上升, 使寒冷、霜冻灾害发生几 率减少. 我国气候增暖虽存在区域差异, 但 1985 年 以后冬、春、秋 3 季的增暖则遍及全国，从而使得我 国 1981 2010 年我国东部温度带出现了整体性北移 和高海拔地区温度带的趋势性上升, 仅由于各地增 暖幅度不同，因而不同气候带的北移或上升幅度也 存在差别.

在干湿区及其界线变化方面, 我国北方半干旱 区及半湿润区总体转干，且其分界线也明显出现东 移与南进, 其中 $36^{\circ} \sim 41^{\circ} \mathrm{N}$ 间的半干旱区及半湿润分 界线移动幅度达 $0.5 \sim 2.5$ 个经度, 使得整个黄土高原 基本转变为半干旱区. 但西北的河西走廊、新疆及青 藏高原的干旱区、半干旱区则总体转湿. 其他地区的 干湿状况虽也有一定程度波动, 但干湿分界线并未 出现明显移动. 这些变化与已有研究 ${ }^{[20,27 ~ 30]}$ 所得到 的认识基本一致. 其原因主要是因为自 20 世纪 70 年 代后期以来，东亚夏季风减弱，从而导致我国华北、 东北东南部、西北东部的降水出现显著减少 ${ }^{[22,23]}$; 同 时受日照时数、风速趋势性下降减缓和增暖及相对湿 度减少等因素的综合影响, 这些地区的最大可能蒸 散在 1993 年后又出现了增加趋势 ${ }^{[31]}$; 从而导致 20 世 纪 90 年代以后这些地区气候转干. 而在西部及长江 以南的大部分地区, 降水则均有所增加 ${ }^{[31]}$; 特别是 西北西部和青藏高原中北部自 20 世纪 80 年代中期以 后增加趋势更为显著 ${ }^{[30]}$, 且同期这些地区的最大可 能蒸散也出现减少趋势 ${ }^{[31]}$, 因而导致河西走廊、新疆 及青藏高原的干旱区、半干旱区总体转湿.

\section{2 资料均一化订正对区划结果的影响}

需要指出的是, 本文所使用的日气象观测数据 虽在发布时就已经严格的数据质量控制、均一性检查 及记录订正与复核, 但同 $\mathrm{Li}$ 和 $\mathrm{Yan}^{[37]}$ 采用序列均一 性多重分析(MASH)订正的“1960 2008 年中国 549站 均一化逐日平均/最高/最低气温数据集”有一定差异. 为分析这一差异, 我们以各区代表站(表 4)为例, 将 本文的日平均气温稳定 $\geqslant 10^{\circ} \mathrm{C}$ 日数、积温、1 月平均 
气温、7 月平均气温 4 个指标的计算结果与利用该均 一化数据集计算得到的结果进行了对比. 在这些代 表站中，两套资料共有的站有 48 个，共有时段为 1981 2008 年共 28 年, 其中二者资料完全一致的站 有 6 个.

2 套资料数据有差异的 42 个站各指标比较结果 如下：(1) 日平均气温稳定 $\geqslant 10^{\circ} \mathrm{C}$ 的日数：二者相差 $0 \sim 1 \mathrm{~d}$ 的站有 26 个, 差 1 3 d 的有 12 个, 差 $3 \sim 5 \mathrm{~d}$ 的 有 3 个; 仅有 1 站(西宁, 52866)相差超过 $5 \mathrm{~d}$, 达 $10.7 \mathrm{~d}$. (2) 日平均气温稳定 $\geqslant 10^{\circ} \mathrm{C}$ 积温: 二者相差 $0 \sim 50^{\circ} \mathrm{C}$ 的 站有 31 个, 差 $50 \sim 100^{\circ} \mathrm{C}$ 的有 8 个; 差 $100^{\circ} \mathrm{C}$ 以上的 仅 3 个, 分别为银川 $(53614), 100^{\circ} \mathrm{C}$; 阿克苏 (51628), $153^{\circ} \mathrm{C}$; 西宁, $195^{\circ} \mathrm{C}$. (3) 1 月平均气温: 二者相差
$0 \sim 0.2^{\circ} \mathrm{C}$ 的站有 32 个, 差 $0.2 \sim 0.5^{\circ} \mathrm{C}$ 的有 7 个, 超过 $0.5^{\circ} \mathrm{C}$ 的有 3 个, 分别为青河 $(51186), 0.52^{\circ} \mathrm{C}$; 阿克苏, $0.72^{\circ} \mathrm{C}$; 西宁, $0.87^{\circ} \mathrm{C}$. (4) 7 月平均气温: 二者相差 $0 \sim 0.2^{\circ} \mathrm{C}$ 的站有 30 个, 差 $0.2 \sim 0.5^{\circ} \mathrm{C}$ 的站有 8 个; 超过 $0.5^{\circ} \mathrm{C}$ 的有 4 个, 分别为西宁, $0.53^{\circ} \mathrm{C}$; 济南 (54823), $0.55^{\circ} \mathrm{C}$; 太原 $(53772), 0.66^{\circ} \mathrm{C}$; 海口(59758), $0.66^{\circ} \mathrm{C}$. 这些差异均明显小于各气候区划分指标的本 身差异幅度范围, 说明未经 MASH 订正的不均一资 料虽会对气候区划指标的计算结果造成影响, 但由 于任一气候区划分指标本身就有一定的幅度范围, 因此这一影响并不足以改变这些站点所属的气候区, 即不会对气候区划分和气候区界线的划定造成显著 影响. 衰心感谢.

\section{参考文献}

1 Fraedrich K, Gerstengarbe F W, Werner P C. Climate shifts during the last century. Clim Change, 2001, 50: 405-417

2 Kalvova J, Halenka T, Bezpalcova K, et al. Koppen climate types in observed and simulated climates. Stud Geophys Geodaet, 2003, 47: 185-202

3 Kottek M, Grieser J, Beck C, et al. World map of the Koppen-Geiger climate classification updated. Meteorol Zeitschr, 2006, 15: 259-263

4 Peel M C, Finlayson B L, McMahon T A. Updated world map of the Koppen-Geiger climate classification. Hydrol Earth Syst Sci, 2007, 11: 1633-1644

5 竺可桢. 中国气候区域论. 见: 《竺可桢文集》编辑小组, 编. 竺可桢文集. 北京：科学出版社, 1979. 124-132

6 涂长望, 郭晓岗. Koppen 范式的中国气候区域. 气象学报, 1938, 14: 51-67

7 卢淦. 中国气候区域新论. 地理学报, 1946, 1-10

8 陶诗言. 中国各地水分需要量之分析与中国气候区域之新分类. 气象学报, 1949, 20: 43-50

9 张宝斿, 朱岗昆. 中国气候区划(初稿). 北京：科学出版社, 1959.1-297

10 钱纪良，林之光. 关于中国干湿气候区划的初步研究. 地理学报, 1965, 31: 12-14

11 中央气象局. 中国气候图集. 北京: 地图出版社, 1966. 162

12 中央气象局. 中华人民共和国气候图集. 北京：地图出版社, 1979. 222-223

13 丘宝剑，卢其尧. 中国农业气侯区划试论. 地理学报, 1980, 35: 116-125

14 李世奎，侯光良，欧阳海，等.中国农业气候资源和农业气候区划。北京：科学出版社, 1988. 191-330

15 陈咸吉. 中国气候区划新探.气象学报, 1982, 40: 35-47

16 中国科学院《中国自然地理编辑委员会》. 中国自然地理一气候. 北京: 科学出版社, 1985. 151-161

17 中央气象局. 中国气候资源地图集. 北京: 中国地图出版社, 1994. 277-278

18 中央气象局. 中华人民共和国气候图集. 北京：气象出版社, 2002.6-7

19 中国标准化与信息分类编码研究所，国家气象中心.中华人民共和国国家标准：中国气候区划名称与代码一一气候带和气候大区 (GB/T17297-1998). 北京: 中国标准出版社, 2004. 1-8

20 郑景云, 尹云鹤, 李炳元. 中国气候区划新方案. 地理学报, 2010, 65: 3-13

21 《气候变化国家评估报告》编写委员会. 气候变化国家评估报告. 北京: 科学出版社, 2007. 23-40

22 《第二次气候变化国家评估报告》编写委员会. 第二次气候变化国家评估报告. 北京: 科学出版社, 2011. 23-38

23 Ren G Y, Ding Y H, Zhao Z C, et al. Recent progress in studies of climate change in China. Adv Atmos Sci, 2012, 29: 958-977

黄荣辉, 陈际龙, 刘永. 我国东部夏季降水异常主模态的年代际变化及其与东亚水汽输送的关系. 大气科学, 2011, 35: 560-589 

sponses. Adv Atmos Sci, 2003, 20: 959-967

27 Yang J P, Ding Y J, Chen R S. The fluctuations of dry and wet climate boundary and its causal analyses in China. Acta Meteorol Sin, 2004, 18: $211-226$

28 Qian W H, Qin A. Precipitation division and climate shift in China from 1960 to 2000. Theor Appl Climatol, 2008, 93: 1-17

29 尹云鹤，吴绍洪，郑度，等. 近 30 年我国干湿状况变化的区域差异. 科学通报, 2005, 50: 1636-1642

30 张永，陈发虎，勾晓华，等. 中国西北地区季节间干湿变化的时空分布一一基于 PDSI 数据. 地理学报, 2007,62: 1142-1152

31 尹云鹤, 吴绍洪, 戴尔阜. 1971 2008 年我国潜在蒸散时空演变的归因. 科学通报, 2010, 55: 2226-2234

32 刘燕华, 郑度, 葛全胜, 等. 关于开展中国综合区划研究若干问题的认识. 地理研究, 2005, 24: 321-329

33 郑景云, 六娟娟. 类型变更的相邻气象观测站的日气温资料整合. 地理研究, 2012, 31: 579-588

34 马开玉, 丁裕国, 屠其璞, 等. 气候统计原理与方法. 北京: 气象出版社, 1993. 449-494

35 Yin Y H, Wu S H, Zheng D, et al. Radiation calibration of FAO56 Penman-Monteith model to estimate reference crop evapotranspiration in China. Agric Water Manage, 2008, 95: 77-84

36 张镱锂, 李炳元, 郑度. 论青藏高原范围与面积. 地理研究, 2002, 21: 1-8

37 Li Z, Yan Z W. Homogenized daily mean/maximum/minimum temperature series for China from 1960-2008. Atmos Oceanic Sci Lett, 2009, 2: 237-243

\title{
The climate regionalization in China for 1981-2010
}

\author{
ZHENG Jing Yun ${ }^{1}$, BIAN JuanJuan ${ }^{1}$, GE QuanSheng ${ }^{1}$, HAO ZhiXin ${ }^{1}$, YIN YunHe ${ }^{1} \&$ LIAO YaoMing ${ }^{2}$ \\ ${ }^{1}$ Institute of Geographic Sciences and Natural Resources Research, CAS, Beijing 100101, China; \\ ${ }^{2}$ National Climate Center, Beijing 100081, China
}

The scheme of climate regionalization in China was conducted by the classification criteria of temperature zone, arid/humid region and climatic sub-region, and the variables used in the criteria were calculated as mean values of the 30 years by using the daily meteorological data of 658 stations from 1981 to 2010. In the classification criteria, the temperature zones were classified by the general guideline of the days with daily temperature steady above $10^{\circ} \mathrm{C}$, and the secondary guideline of January mean temperature, or by their referenced variables including the accumulated temperature with daily temperature steady above $10^{\circ} \mathrm{C}$ and annual minimum temperature, respectively. The arid/humid regions were classified by the annual aridity index and annual precipitation amount in turn. The climatic sub-regions were classified by the July mean temperature. The result shows that China can be divided into 12 temperature zones, $24 \mathrm{arid} /$ humid regions and 56 climatic sub-regions. Compared with the climate regionalization scheme for the period of 19511980, several boundaries of temperature zones in eastern China shifted northward in 1981-2010 due to the climate warming. The east part of the northern boundary of warm temperate zone shifted more than $1.0^{\circ}$ at a maximum. On average, the east part of the northern boundary of north subtropical zone shifted $1.0^{\circ}$. The middle part of the northern boundary of mid-subtropical zone shifted $2.0^{\circ}$ at a maximum. The west part of the northern boundary of south subtropical zone shifted $0.5^{\circ}-2.0^{\circ}$. In West China, the shift of temperature zone was not significant in horizontal due to the vertical landform. However, the plateau sub-cold zone was shrunk while the plateau temperate zone was enlarged in the Tibetan Plateau. Because precipitation decreased in North China, southeastern part of Northeast China and eastern part of Northwest China, the boundary of the semi-arid and sub-humid region in Northern China shifted eastward and southward, and in which, the boundary between $36^{\circ}-41^{\circ} \mathrm{N}$ shifted $0.5^{\circ}-2.5^{\circ}$ at longitude. Moreover, the climate in the most of arid regions and semi-arid regions in Hexi Corridor, Xinjiang and the Tibetan Plateau changed to be more humid.

China, 1981-2010, climate regionalization, shift of boundaries of regionalization

doi: 10.1360/972012-1491 